\title{
LIII. History of astronomy for the year 1805
}

\section{Jerome de Lalande}

To cite this article: Jerome de Lalande (1807) LIII. History of astronomy for the year 1805, Philosophical Magazine Series 1, 26:104, 347-362, DOI: 10.1080/14786440708563684

To link to this article: http://dx.doi.org/10.1080/14786440708563684

$$
\text { 册 Published online: } 18 \text { May } 2009 .
$$

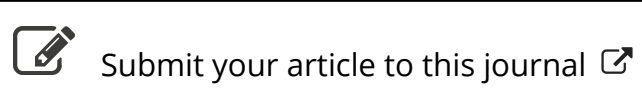

\footnotetext{
山 Article views: 2
}

Q View related articles $\longleftarrow$ 
prove more than equivalent to the duties at present collected.

Since writing the above, I am informed by a person wha deals largely in foreign oils, that letters from Leghorn annopnce an alarming deficiency in the last year's product; that the quantity is very small, and of a very inferior quality. This information should operate as an additional motive to the attempt recommended. The injury induced upon olive trees by inclement weather is frequently to such an extent, that it can only be repaired by the slow growth of new plantations. This circumstance gives an astonishing advantage to a substitute, of which, by its.being an annual product, the deficiency of the most unfavourable year cannot be equally extensive, and would probably be supplied by the increased abundance of the year ensuing.

\section{LIII, History of Astronomy for the Year 1805. By JEROME DE LALANDE. \\ [Concluded from p. 253.]}

$\mathrm{T}$ The meteorology of 1805 has been remarkable for the variations of temperature. It froze in the morths of March, June, and September: on the 17 th and 18 th of December a degree of cold of from $6^{\circ}$ to $7^{\circ}$ froze the Seine at Paris; and on the 31 st we had the same temperature as in spring.

On the 7 th of December, at eight o'clock in the evening, at Basle, in Switzerland, the inhabitants thought themselves at the mouth of a furnace. This heat lasted three hours.

There was a hurricane on the 13th of December, in which several vessels were lost.

Perhaps the auroræ boreales, which have such an intimate connection with electricity, and which are constant in the north, may occasion storms which determine the winds, and contribute to these unaccountable variations of the seasons in our country.

There happened a phænomenon this year which furnished me with an opportunity of explaining the origin of hurricancs. At Belfort, on the 4th of July, there was one of those hurricanes, so rare and extraordinary in Europe, which 
tore up trees, and unroofed houses. Hitherto I had not been able to ascertain the cause ; but my journey to Lyons furnished me with an idea which might be realized. M. Molet, an intelligent medical professur, found, from his notes, that it thundered that day at Lyons. In passing through Sens I saw $M$. Soulas, who informed me that the wind had changed from north to south. The journals informed me that there was a dreadful storm at London on the same day.

There is, in my opinion, a mass of electrical clouds of 100 myriametres in extent, the detonation of which had made an immense vacuum, and that the air rushed with great violence to fill up this vacuum. I bad a confirmation of this on the 11th of January 1806. Some dreadful claps of thunder at Brest, Rouen, Chartres, and Ypres, produced tempests and hurricanes which overturned the chimneys of the houses at Bourdeaux, Besançon, Nancy, and Dijon. Loud claps of thunder are very rare at this time of the year, but the south wind made it very hot; the atmosphere was rainy, the lower olouds were near enough to draw sparks from the earth to an extent of 60 myriametres : there were alsa earthquakes at the same time.

The hurricanes of the Isle of France and America, which are much more violent, require us to suppose the stormy masses much larger; but to these must be added waterspouts and submarine eruptions.

M. Fiot, inspector-general of health, has sent me the results of the heights of the river, observed every day during the year 13. The mean state of the river this year was $1 \cdot 3.5$ metres on the scale of the bridge of La Tournelle, instead of 1.24, which I had found by a mean of eighteen years, 1777-m 1794. The year 13 has been considered as a rainy year, nevretheless there have been years of 1.73 , as 1787 ; whilst in 1803 we had only 059 . This height is relative to the low water of 1719; but the river has sometimes been lower by some centimetres.

The Turin Academy has published its memoirs for 1804 and 1805 , in which there is a new barometer of M. VassalliEandi, with heights measured in Piedmont.

M. Beraud, who for these thirty years past has made an im- 
mense quantity of meteorological observations in Piedmont, and who still continues them, notwithstanding his great age, has sent us those of 1805 .

Meteorology and navigation may equally claim a menoit by $\mathbf{M}$. Biot, which explains, by means of an interior magnet, all the declinations and inclinations of the needle observed by $M$. Humboldt in his travels.

There is an unpublished memoir of Tobias Mayer, of which his son had the goodness to send me an extract. It contains an hypothesis by which he explains the observed inclinations and declinations. He supposes a very small magnet in the interior of the earth having two poles, the centre of which magnet is removed from the earth by oneseventh of the radius, and recedes from it each year one thousandth part.

The line drawn from the centre of the earth through that of the magnet was in 1750 at $201^{\circ}$ of longitude and $17^{\circ}$ of north latitude : the longitude increases $8^{\prime}$ a year, and the latitude $1 x^{\prime}$.

The axis perpendicular to the line joining the centres, drawn in such a manner that the plane which passes by this axis and this line, is inclined to the meridian of this line $11 \frac{1}{2}$ degrees towards the east on the north side; and this angle increases $8 \frac{1}{2}$ minutes a year.

M. Azuni has published a dissertation upon the origin of the compass, in order to prove that the French were the first who used it: it was known in France in the 12 th century, by the name of mariniere: it was used in the reign of Saint Louis. Gioia d'Amflai, to whom it has been attributed, did not live till about the year 1300. The figure of the fleur de lys has been used in the compasses of all nations. I have already remarked, in my Abridgment of Navigation, that father Ximenes, the celebrated Italian astronomer, has proved the priority of the French in his work Del Gnomone Fiorentino, p. 59.

Mr. Earnshaw and Mr. Arnold, two English watchmakers, on the 7 th of June 1804 presented to the Board of Longitude of London their escapements for tine keerer $r$ s 
or chronometers; and the Board of Longitude has published them. That invented by M. Breguet at Paris, is described in the volume of the History of Mathematics of Montucla, where I have given the history of machines.

Nautical astronomy has been enriched with an important book entitled "A complete Collection of Tables for Navigation," by M. Mendoza, a Spanish officer, who has resided some time in England; comprised in 727 pages, in large quarto. It contains all the tables necessary for correcting the altitudes and distances by the simplest method hitherto found out; for it is reduced to the addition of three numbers; which we take from these tables. We have also tables of logarithms, semi-diurnal arcs, amplitudes, the most extensive table of the longitudes and latitudes of places on the earth, and, generally speaking, every thing that is requisite at sca. If we add to the above the horary tables which I published at great length in my Abridgment of Navigation, in 1793 , sailors will require nothing more to know when they are in any part of the world; and I hope that, in spite of all the efforts of the English, the French will not be the last to profit by these advantages, under an emperor who is so well acquainted with the importance of a navy.

These tables render the calculations so easy, that navigators would do wrong not to use this method of finding the longitude. M. Mendoza is at present occupied with a more complete treatise on nautical astronomy.

M. Luyando has published at Madrid twenty-three charts, upon which we may find, by a pair of compasses, the sides or angles of spherical triangles within a few minutes, and the correction of the distances observed at sea within a few seconds. These charts, as well as those of M. Margett's, at London, may be useful to navigators who are not fond of calculations. Those of M. Luyando will cost less, but their use is rather more difficult.

M. Duval le Roi has published at Brest, Elements of $\mathrm{Na}$ tigation, which are worthy of that able professor.

M. Depaquit has published a new Theory of the Tides. 
I did all I could to dissuade bim from it: niy efforts have been in vain; and I only mention this to prevent the public from being deceived.

The observations of the tides have been continued in several harbours : at St. Maloes, by M. le Cerf ; at Ostend, by M. Porquet; at Sables d'Olonne, by M. Depoge.

The tide at Brest, at the spring equinox, having taken place with an east wind, I requested some observations of it, and I found that it had not surpassed the mean tide; which completely confirms the system I have laid down in my treatise upon the fux and reflux of the sea, - that when the equinoxial tides are highest, it is occasioner by the wind.

Geography has been enriched by various important voyages. That of Hearn has been published, made between 1769 and 1772 , to the north-west of Hudson's bay. It extended from Churchill's river, which flows into the bay, to the $72^{\circ}$ of latitude, an extent of 100 myriametres, in the country of the Esquimaux who inhabit the neighbourhood of the Copper river. The maps of North Autrica will be much altered by this voyage. The communicafion from sea to sea, so often spoken of, secms to be more and more illusory.

Captain Krusenstern, the commander of two Russian vessels, with which he sailed round the world, arrived at Kamschatka on the sth of August, 1804 ; after having doubled Cape Horn and landed upon the Marquesas and $S$ andwich islands, he proposes visiting China and Japan. The account of this voyage will be very interesting, and will do honour to the Petersburgh Academy, who obtained permission from the emperor of Russia for it to be undertaken.

In the 28th number of the Annals of the National Museum of Natural History, February 1805, we find that caytain Lewis is gone to reconnoitre the Missouri as far as its source. He will afterwards search for the nearest river to the westward, and will descend by it to the Pacific Ocean. This cxpedition, composed of twelve persons, will probably spturn in a few months. The president, Mr. Jifferson, in- 
tends sending persons to explore some other rivers which as yet are absolutely unknown.

On the 6th of February 1805, Mungo Park sailed from Portsmouth, in order to return into the interior of Africa, where he before made an interesting expedition.

Lieutenant Ohlsen is occupied in drawing a map of Iceland. He speaks of a boiling spring at Stort, which first made its appearance in 1784 . It throws up the water to the height of 300 feet. This proves that there is a great deal of water in the interior of the earth, and supports the bypothesis by which I have explained the sinking of the waters which covered our mountains, and which I think nust have entered into the interior cavities.

M. Schubert, the able astronomer of Petersburgh, has set out for China with the Russian embassy. We may therefore expect from him some good observations on the geography of Asia. We understand that the embassy had arrived upon the frontiers after a journey of 600 myriametres, and that they were within 130 myriametres of Pekin; but the Chinese are not fond of much company, and M. Schubert returns by the north : his journey will be very useful in many respects.

M. Portalis, minister of religion, wishing to send some missionaries to China, concerted for that purpose with M. Brunet, the superior of St. Lazarus. They hope to be able to set out this year, accompanied by an astronomer, who is already preparing his instruments. The manuscripts collected by $M$. Bertin on the subject of China, are in the hands of a secretary, who has offered to sell them to government. M. Billien and M. Abarie, attached to the foreign missions, have been in China, and know the Chinese well. Thus we have not lost all hope of seeing this branch of knowledge come again into favour in France.

The geography of Europe has also received some recent alvantages. M. Benzenberg writes from Dusseldorf, that the king of Bavaria has ordered some accurate maps of the country of Berg to be drawn.

M. Henry has returned from Alsace; on account of the 
war, he could not venture into Spain to continue the measurement of the meridian. He will resume his triangies for his degrees of longitudes, or rather he will continue his triangles of Helvetia.

M. Hennet, imperial commissary of land-surveying, has published the laws, arrêts, and instructions, the circular orders and decisions on that subject, in two volumes octavo. He will give a third in 1806 . They are busily occupied in drawing plans of every part of France.

The chief geometer of the department of Aveyron, and the learned professor at Rhodes, M. Tedenat, are occupied in rectifying the principal points of the plan with a circulat instrument of eight inches radius, made by Messrs. Becker and Michel, which gives the angles certain to two seconds.

While we have been waiting for this complete and detailed description of France, there has been published a geographical, statistical, historical, and political dictionary of France, containing a description of the cities, villages, the history, population, mineralogy, hydrography, commerce; natural and artificial productions, the old and new government, the civil, military, and ecclesiastical institutions, and a dictionary of the colonies, with a general map, \&c. in five large volumes in quarto. Fifteen years' labour has been bestowed on this great work, and much pains and expense : several men of learning have assisted in it ; they are not named, but they certainly deserve to be known. The dictionary of Expilly, in six volumes folio, was never finished, although $I$ had repeatedly requested it might : this perhaps will supply the place of it.

As it is necessary we should conclude our History of Astronomy with an account of the losses it has sustained, I shall begin with M. Ratte, who, as an astronomer, has for a long period been an honour to the academy of Montpelier.

Etienne-Hyacinte de Ratte, son of Jean-Pierre de Ratte, and of Gillette de Flaugergues, wds born at Montpelier the 1st of September, 1722. His taste for the sciences, and principally for mathematics, displayed itself veryaearly: he had masters of every kind; he studied all the sciences with ardour, and the extent and the variety of bis acquirements 
at so early an age, astonished the literary characters who were then very numerous at Montpelier. The Royal Society of Scisnces established in that city in 1706, were anxious to receive among them so promising an associate, and in spite of the regulation, rcquiring the members to be twenty years of age, that requisite was dispensed with in favour of young de Ratte, who in 1741 was admitted a member. In the year following he was elected perpetual secretary; the duties of which function he continued to discharge with the greatest credit until the Royal Society of Montpelier was suppressed. He published some volumes in 1766 and 1778 , under the tille of Memoires, afterwards under the title of Assemllées et Bullotins, and in every volume there are some articles, eulogies, and memoirs of his composition. His culogics on Plantade, Clapies, Lapcyronie, Venel, Lafosse, Pitot, Sauvage, Linné, Leroy, Lamure, \&rc. have proved both the extent of his knowledge and his ability as a writer.

He also composed several physical and mathematical memoirs upon vortices, fluids and aloes, which are printed in the Collections of the Royal Socicty ; and he furnished for the French Encyclopedie the articles cold, ice, hail, \&c.

The famous prediction of Halley, respecting the return of the comet of 1682 , which he fixed about 1757 or 1758 , occupied the altention not only of astronomers, but also of all the scientific men of the day. M. de Ratte was anxious to participate in the discovery of this comet; and this was the occasion that determined him to pursue the study of astronomy. He was among the first who discovered it at its issuing from the sun's rays. These observations gave him pleasure, and he never afterwards omitted observing every comet any way remarkable. He also observed the transit of Venus in 1761: the observation which he made of it at Montpelier was one of the most complete; and it became the basis of much calculation upon the sun's parallax, with which $M$. Ratte was occupied. He afterwards made several observations upon the iransits of Mercury over the sun, upon the eclipses of the sun and moon, the satellites of Jupiter, and occultations of the stars; the greatest part of which have never been published. He di- 
rected $M$. Poitevin's studies towards astronomy, who is still occupied with it, and whose observations have been frequently printed. He often regretted very much, that no astronomer was established to make use of the observatory of Montpelier.

M. de Ratte, the father, died in 1770 : he was deacon of the counsellors of the court of aids at Montpelier. The wishes of his family and of the public engaged M. Ratte, jun. to take that office upon him; and he discharged the duties of it, until the suppression of the court of aids, in the most distinguished manner. He was often the principal urgan of that assembly' on important occasions and in times of difficulty : it was totally set aside, ho.vever, in 1793.

At the conclusion of the reign of terror, the members of the old Royal Society who had the good fortune to cscape proscription, conceived the idea of re establishing it under the name of the Free Society of Sciences and Belles Lettres. This idea succeeded; the society was formed, and M. de Ratte was at first appointed secretary, and then president. This society has already published two volumes of its memoirs under the title of Bulletins, which contain interesting researches and observations. There is a discourse by M. Ratte in the bulletin of the $3 d$ of May, $180 \mathrm{f}$. We there see that his zeal set his age at defiance.

M. de Ratte was chosen a non-resident associate of the National Institute; and afterwards named a member of the legion of honour.

He had enjoyed the most perfect state of health during the whole course of his life; but he was latterly attacked with a retention of urine, the attacks of which becoming very frequent, were exceedingly painful ; but the habit he had taught himself of suffering without complaining, and his natural gaiety, made his friends forget that he was unwell. He was present at the academy on the 24th of June, 1805; and it was not until the night of his death that he was thought in danger. He expired on the 15th of August, aged 83 .

M. de Ratre was of a low stature; he had a happy and intelligent physiognomy; he conversed with pleasantness and 
good humour; be never contradicted any one; and he always descended to the level of every person with whom he conversed: his modesty and simplicity were extreme; and it was surprising to find in a man so consummately learned, the candour and simplicity of a child : his memory was surprising : he lived a life of celibacy, and by his death, the house of Ratte, established in Languedoc since 1433, became extinct. This family was originally from Bologna in Italy, and was known so early as the year 1125 by the talents and virtues of Hubert de Ratte, cardinal and archbishop of Pisa, and by the military exploits of Jean de Ratte, count of Caserta in the kingdom of Naples.

The astronomical observations of $M$. de Ratte have been collected by his nephew $M$. de Flaugergues, at Viviers. M. Poitevin, sccretary of the academy, who is also an astronomer, has published his eulogy at great length at Montpedier.

We have also lost M. Romme, an able professor of navigation at Rochefort. He had laboured in astronomy along with me in his youth ; I procured a place for him at Rochefort, and he made several observations.

In 1771 he published a method for determining the longitudes at sea; in 1800 he gave a model of a calculation for finding the latitude and longitude at sea, wherein he scems to think the method of Borda inconvenient in certain cases. M. Delambre, in the Connoissance du Temps, An XII. p. 263, has shown that several authors are actually mistaken in thinking that the sum of the two altitudes and the distance surpasses $180^{\circ}$; but this cannot happen.

Romme gave in 1778 the art of mast-making; in 1781, that of sail-making; in 1787, L' Ari de la Marine, or principles and general precepts on the art of building, manœuvring, and steering vessels; a work very much esteemed among navigators.

He had composed several other works, which Barois the elder was upon the point of printing in 1798 ; but $I$ was particularly desirous of seeing published his tables of the winds, the tides, and the currents in every sea; which appeared in two volumes in octayo. In 1700 he sent $\mathrm{me}$ 
some curious observations upon the tides of the Charante; in which there are some particular circumstances which I intend to publish in a second edition of my Treatise on the Flux and Reflux of the Sea.

In 1787 he made some experiments upon the resistance of water, which ship-builders are much in want of. I have given the result of them in Montucla's History of Mathematics, tome iv. p.454, according to the account given by the commissaries of the academy. He gave a marine vocabulary in French and English; and perbaps no person was ever more usefully or more constantly employed in this grand art, which is the principal source of the prosperity and grandeur of states.

He was brother to the deputy, who obliged me to make the republican calendar in 1703 , and who perished in the troubles of the revolution on the $17 \mathrm{tb}$ of June, 1795 ; the latter had been tutor to the children of count Stroganoff, a Russsian nobleman, who resided a long time at Paris.

We have also lost $M$. de Chabert, a celebrated navigator, of whom I shall speak more at length.

Joseph Bernard de Chabert, ci-devant marquis, chef d'escadre in the nary, commander of the orders of Saint Louis and Saint Lazarus, inspector of the marine depot, free associate of the Academy of Sciences, and lately member of the Board of Longitudes, and of the Royal Societies of London, of Berlin, Stockholm, Bologna, and Brest, was born at Toulon, 28th February, 1724. He was the son of an officer of the royal navy, and he entered into the service in 1741 ; his father, when dying, caused himself to be carried on board the ship commanded by his son, and said, "I shall now die without regret."

In 1746 he went to Nova Scotia in a French squadron. He then saw how very defective the maps of America were; he was a witness to the dangers our vessels experienced, and he gave an account of them upon his return. Lemonnier undertook to request permission of the minister to allow him to remain at Paris for the purpose of studying astronomy, that he might go and remedy the inconveniences he frad met with, and encourage the officers of the navy to 
pursue the study of a science which equally contributes to their glory and their security. At the age of thirty he received the cross of St. Louis, which he preferred to a pension. At the return of peace in August 1748, he presented a prospectus of the voyage and the observations. M. Rouillé and M. de la Gallissoniere furnished him with instruments; he set sail in 1750 , in a frigate commanded by the marquis cie Choiseul-Praslin, and he executed a chart of the coasts of Nova Scotia and Newfoundland, and of the banks and islands in the Gulf of St. Lawrence. I had the saisfaction of furnishing him with an object of comparison by my first observation of an eclipse of one of the satellites on the 24 of October, 1750. His voyage was printed in 1753 , in 288 pages in quarto. It contains observations on the magnet and upon currents; details upon the calculations which navigators require; all of which evince that he had already become a very good astronomer, and his example cxcited cmulation in the navy, where it was much wanted. The first volume of the Savans Etrangeres, published by the academy in 1750 , contains a memoir of $M$. de Chabert upon the longitude of Bucnos Ayres. In the history of the year 1756 , his observations made in 1753 along the coast of Spain and at Port Mahon are mentioned. In 1756 he gave several other memoirs upon the transit of Vellus, upon hurricanes, and the eclipse of 1760 .

In 1758 he was received a member of the academy; and on the 25th of April, 1759, he read at his public entry into it his idea of constructing charts of the Mediterranean, for the purpose of making a second volume of the Neptune Français, published in 1693, and thereby following the labours of Chazelle and Fcuillée, who died in 1710.

He set out on the first of May, 1764: after having laid down the eastcrn coast of Spain, he passed into Sardinia, and crossed over to $F_{c} z$, Algiers, and Tunis, where he succeeded in determining several important longitudes, by means of a transit instrument which he fixed on shore, and which he succeeded in placing in a few hours exactly in the meridian.

In 1767 , after having sailed round the coasts of Sicily, lie 
he steered for Tunis : he then went to Tripoli, and returned into the Adriatic gulf. In 1768 be commanded the Ilirondelle, in 1775 the Mignonne, and in 1770 the Atalanta, on board of which was $\mathrm{M}$. Choiseul. He was in possession of a time-keeper, without which he conld not have drawn the chart of the Cyclades and that part of Greece adjoining: he had reserved this business to the present opportunity, The inscription he cansed to be engraved in the grotto of Antiparos proves his great learning, and will be a monument of it to future travellers. At his return our able astronomer Mechain, being attached to the depôt of which M. de Chabert was director, passed several years of his life in reducing and calculating this immense quantity of observations, which had cost so many years of labour and travelling, and from which resulted the best cliarts of that part of the Mediterranean. Several times he was in imminent danger of his life. I hope his journal will be published, as it cannot fail to excite considerable interest from the anecdotes I have heard him relate.

The American war obliged him to exchange his scientific labours for the military marine service in the naval armaments of generals d'Estaing and De Grasse. In 1778 he commanded the Valiant in d'Estaing's fleet: in 1780 he had the Saint Esprit: he fought a battle, near the Chesapeak, with five English ressels, on the 5th of September 1781 : he relieved the Diadem, which the English were very near having taken. He brought safely into a French port a convoy of 130 sail; he was then named chef d'escadre, and received the red ribbon; this was the reward of twenty-two naval campaigns, in fifteen of which he commanded corvettes, frigates, or ships of the line : he sailed during the whole of the war, which ended in 1783, first as commander of a vessel and afterwards as chief of a division, without ever neglecting his astronomical observations and the use of the time-keepers, as may be seen in the Memoirs for 1783 .

The misfortunes of the revolution obliging him to remove from France, he went to England, where Dr. Maskelyne paid him evcry attention that could be expeeted from one great astronomer to another, giving him an unlimited credit 
upon his banker *, which M. de Chabert, however, would rot make use of. He lost his sight suddenly in 1800; and this misfortune can only be attributed to his excessive labour in calculating observations. Having returned to Paris in 1802 , be was received in the most distinguished manner by those heroes of France who were best acquainted with his talents and bravery. He received a pension in the month of December 1804 : he was elected a member of the Board of Longitude, and woukl have been included in the reorganization of the Institute in 1803 , had there been a vacant place. On the 4 th of January 1805 he presented to the Board of Longitude a chart of Greece, with the particulars of the coast: and I trust we shall find many useful things among his immense collection of materials. Although blind, he never ceased his labours : he generally wrote or dictated until nine o'clock every evening; and when M. Nevev, his sccretary, left him, he always felt regret. We have many times found his memoir useful in the geographical discussions of the assembly. Some days previous to his death he asked me for some observations which I had received from Spain, in order to compare them with his own; and two days before his death he desircd some passages of his Memoirs upon Pensacola, in Spain, where he laboured in 1768 , to be read to him. Whenever his journals are published, the world will be astonished at his ardour, his accuracy, his labours, his dangers, and the presence of mind with which he remedied all the inconvenient circumstances that opposed his pursuits.

An inflammation of the lungs carried him off in nine days; but he died without pain, consoled by religion and adored by a beloved family.

He married, in $17 \pi 1$, mademoiselle Tascher, the daughter of a gentleman at Coire, in the Grisons, and sister of a late president, who was intendant of the Isles-du-Vent, and

* It is presumed Lalande has mistaken Dr. Maskelyne for sir Joseph Banks in this account; for he lived almost the whole time either with sir Joseph or at his expense. Dr. Maskelyne was always very civil to him, and the marquis usually spent about a month at the royal observatory every summer during his stay ia England. 
who was considered the best informed man in Paris, anl frequented as such by men of letters. M. de Chabert left one daughter, madime Ruland, wiso, in concert with her mother and her husband, afforded the greatest comfort to this excellent man. M. Roland, who has been already distinguished by his travels in Egypt, is at present attached to the army of Naples, and his extensive knowledge wiil enable him to profit by his interesting travels.

No person is better qualified to speak of $M$. de Chabert than myself, who bave known him since the year 1750 , and have lived with him: his benevolence and his mildness were universally admired by his inferiors. He once found a newborn infant upon a desert, nearly dying, whom he reared and educated. She became an interesting girl, but died too young to enjoy the full extent of his bounty. M. de Chabert was one of the first among the officers of the navy to show an example of zeal and learning: he was also one of the first who made use of his dignity to promote the good of the service itself; and his memory will be preserved among those who have rendered service to all nations, since the navy is one of the sources of their prosperity, as it is one of the means of inproving the human species. M. de Missiessi, known by his campaign in America in 1801, and by his work on the stonage of vessels in 1789 , was the son of a first cousin of his; and the name of this worthy successor of his fame was in the expiring lips of his illustrious parent.

On the gth of September we lost M. Dulague, born at Dieppe on the 26 th of Deceniber 1729, an ahle professor of navigation at Rouen, to whom we are indebted for several works and obscrvations. The Academy of Rouen will publish his eulogium.

M. Losage, who dicd at Gencra, was occupied with celestial philusophy. His Newtonian Lucretius, upon the cause of miversal gravitation, is a curious work, which I have quoted in my Astronomy, art. 3530.

Victor Comeiras, who died in the month of October, published Bailiy's History of Antient and Modem Astronomy, in two rols. 8vo, and thereby brought that work within 
362 On the Adulleration of Wines with Litharge.

within the reach of a greater number of readers by reducing the price.

M. Arago, secretary to the observatory, devotes himsclf entirely to'astronomy, and we have reason to hope he will repair our losses.

Isaac Lalande, the third of the name, has begun to turn his attention to astronomy: he both calculates and observes. The first eclipse which he calculated made us acquainted with an error of a quarter of an hour in the calculation of the next eclipse. I baptized him Isaac in honour of sir Isaac Newton, whom I wish him to take for his pattern, and that he might always have him in his memory.

M. Contè, who dicd on the 6th of December, at the age of fifty years, was not decidedly an astronomer, but his labours in aërostatics authorise me to speak of his loss here; which is,indced, truly lamentable both for the arts and sciences, or, in more extensive terms, for the whole human species.

IIV. Method of ascertaining whether Wines are adulterated with Litharge. By M. Navche, Physician*.

The property possessed by litharge, or the demi-nitrous white oxide of lead, in depriving wines of a bad quality of their bitterness or pungency, and thereby rendering them mild and pleasant to the taste, has induced some avaricious speculators to raise the price of their wines by adding a certain quantity of litharge to them.

This reprehensible practice, occasioning colics and various other diseases, renders it dangerous to use wine. It is necessary, therefore, to be in possession of the means of ascertaining this adulteration, or of ascertaining the innocence of such persons as may be unjustly accused of it.

The agents employed for this purpose are the sulphuric acid, and water charged with sulphuretted hydrogen gas.

When pure sulphuric acid is poured upon wine contain-

* From Billioth. Phys. Econ. July 1806. 